\title{
Phylogenetic Framework and Biosurfactant Gene Expression Analysis of Marine Bacillus spp. of Eastern Coastal Plain of Tamil Nadu
}

\author{
Sreethar Swaathy, ${ }^{1}$ Varadharajan Kavitha, ${ }^{1}$ Arockiasamy Sahaya Pravin, ${ }^{1}$ \\ Ganesan Sekaran, ${ }^{2}$ Asit Baran Mandal, ${ }^{1}$ and Arumugam Gnanamani ${ }^{1}$ \\ ${ }^{1}$ Microbiology Division, CSIR-Central Leather Research Institute, Adyar, Chennai, Tamil Nadu 600 020, India \\ ${ }^{2}$ Environmental Technology Division, CSIR-Central Leather Research Institute, Adyar, Chennai, Tamil Nadu 600 020, India
}

Correspondence should be addressed to Arumugam Gnanamani; gnanamani3@gmail.com

Received 15 October 2013; Accepted 17 December 2013; Published 12 February 2014

Academic Editor: Rodrigo E. Mendes

Copyright @ 2014 Sreethar Swaathy et al. This is an open access article distributed under the Creative Commons Attribution License, which permits unrestricted use, distribution, and reproduction in any medium, provided the original work is properly cited.

\begin{abstract}
The present study emphasizes the diversity assessment of marine Bacillus species with special reference to biosurfactant production, respective gene expression, and discrimination among Bacillus licheniformis and Bacillus subtilis. Among the 200 individual species of eastern coastal plain of Tamil Nadu screened, five biosurfactant producing potential bacterial species with entirely different morphology were selected. Biochemical and 16S rRNA gene sequence analysis suggested that all the said five species belong to Bacillus genera but differ in species levels. Biosurfactant of all the five species fluctuates in greater levels with respect to activity as well as to constituents but showed partial similarity to the commercially available surfactin. The expression of srf gene was realized in all of the five species. However, the sfp gene expression was observed only in three species. In conclusion, both $B$. licheniformis and B. subtilis demonstrate $s r f$ gene; nevertheless, sfp gene was expressed only by Bacillus subtilis.
\end{abstract}

\section{Introduction}

Biodiversity is given by a variety of species living on earth resulting from billions of years of evolution. Molecularphylogenetic studies have revealed that the main diversity of life is microbial and it is distributed among three domains: prokaryotes, eukaryotes, and archaea. The functioning the of whole biosphere depends absolutely on the activities of the microbial world. Due to versatility, microbes are the major natural providers of ecological services as well as playing major role in semiartificial systems such as sewage treatment plants, landfills, and in toxic waste bioremediation. However, because of the continuous exposure to man-made synthetic molecules a large change/reduction in microbial diversity has been realized. Several publications document the effect of chemical pollutants on microbial community structure based on the available sequencing technologies [1]. Metagenomics, metatranscriptomics, metaproteomics, and singlecell sequencing are the approaches providing a view not only of the community structure (species phylogeny, richness, and distribution) but also of the functional (metabolic) potential of a community.

Among the various sources, microbes of marine waters/sludges received good attention because of the wide potential biological products with immense applications [2]. Most of the products are used to recover oil [3-5]. In addition, the interest in marine bacteria arises from their biotechnological potential in bioremediation [6] and in oceanic biogeochemical cycles [7] and as a source of novel metabolites different from those isolated from terrestrial bacteria, such as antibiotics [8] and products for industrial use like exopolysaccharides, enzymes [9], biosurfactants, and compatible solutes [10]. Most of the available investigations focused on the two groups of bacteria, the members of the genera Bacillus or Pseudomonas, due to the resourcefulness and applications $[5,6,11-15]$. With regard to Bacillus genera, it consists of more than 222 recognized species (http://www .bacterio.cict.fr) distributed widely across many terrestrial 
and aquatic habitats [15, 16] including marine sediments [17]. Members of the genus Bacillus comprise Gram positive, spore forming, rod-shaped, and aerobic bacteria. Bacillus species are phenotypically and genotypically heterogenous [18]. Few studies have focused on the phylogeny and biodiversity of marine Bacilli $[15-17,19]$. These reports were based on a small number of isolates or a unique sampling site and showed that Bacillus subtilis, Bacillus licheniformis, Bacillus cereus, Bacillus amyloliquefaciens, and Bacillus pumilus are the common inhabitants of marine environments and consequently often isolated. However, a more extensive analysis to assess the real biodiversity and phylogenetic relationship between Bacilli from marine origin is becoming necessary. Recent studies on marine bacilli showed that strains of B. marinus, B. subtilis, B. pumilus, B. licheniformis, $B$. cereus, and B. mycoides are common inhabitants of the marine habitat [15]. They constitute closely related taxa and their differentiation has become difficult and laborious, as they cannot be distinguished from each other by phenotypic tests.

Furthermore, with regard to biosurfactant production, certain strains of the closely related species $B$. subtilis, $B$. mojavensis, B. sonorensis, and B. licheniformis produce the cyclic lipopeptide biosurfactants, surfactin, and lichenysin [20-23]. B. subtilis produces a known lipopeptide biosurfactant called surfactin, which is coded by four open reading frames (ORFs) named as SrfA, SrfB, SrfC, and SrfD [24]. Similarly, lichenysin is a lipopeptide biosurfactant produced by $B$. licheniformis coded by lichenysin operon (LchA) and consists of three peptide synthetase genes: LicAA, LicAB, LicAC, and LicAD [21]. B. cereus produces a lipopeptide biosurfactant called plipastatin [25].

The species most closely related to $B$. subtilis are unusually similar at the phenotypic level. For example, fatty acid composition is the only known phenotypic character that distinguishes Bacillus mojavensis and Bacillus vallismortis from one another or from B. subtilis $[26,27]$ and Bacillus atrophaeus is distinguishable from $B$. subtilis only by differences in pigmentation [28]. A heterogeneous group of moderately halophilic bacteria, which comprises Bacillus salexigens, and three species of the new genus Halobacillus, $H$. halophilus, $H$. litoralis, and $H$. trueperi [29-31], may be differentiated by their ability to grow at 10 to $20 \%$ of total salts and the possession of an unusual type of murein. Molecular methods have proven to be more effective in distinguishing close relatives of $B$. subtilis.

From the above-summarized information, it has been understood that discrimination of the Bacillus species based on the morphology, phylogenetic framework and gene expression of molecule of interest is possible; nevertheless, the closely related species with similarity in the byproducts need intensive explorations.

Thus, exploring the phylogenetic markers such as $16 \mathrm{~S}$ rRNA genes to reveal microbial diversity and further exploration of gene expression to reveal the functional power of the microbes is essential. Hence, in the present study, phylogenetic framework of marine Bacillus spp. and expression of gene responsible for biosurfactant production has been explored in detail, which provided interesting information and highly relevant to identification of novel strains with desirable functional characteristics and biotechnological applications.

\section{Materials and Methods}

2.1. Isolation and Maintenance of Organism. Marine samples of water, sediments, mussels, shells, sea weeds, and sand were collected from Kalpakkam, Ennore port, Besant Nagar Beach, Marina beach, Mahabalipuram beach, Mandapam, Vedaranyam, Tuticorin, Cuddalore in Tamil Nadu, India (Figure 1). Zobell marine broth/agar (for bacteria) was the media used for the isolation of microbial species according to the standard procedure employed for the isolation and maintenance of marine organisms. Morphologically distinct organisms were selected and stored in 30\% glycerol stock at $-20^{\circ} \mathrm{C}$.

2.2. Screening of Biosurfactant Producing Microbes. Biosurfactant producers were screened based on the surfactant activity exhibited by the culture media after 24-72 hours of incubation at $37^{\circ} \mathrm{C}$ in the presence of the bacterial isolates. In brief, Zobell marine broth (Hi Media) $(100 \mathrm{~mL}$ in $1000 \mathrm{~mL}$ capacity conical flask) was sterilized and inoculated with the isolated cultures and was incubated at $37^{\circ} \mathrm{C}$ for $24-72$ hours under shaking condition. Followed by incubation, the samples were made cell-free by centrifugation at $10,000 \times \mathrm{g}$ at $4^{\circ} \mathrm{C}$. Biosurfactants activity of the cell free medium was assessed according to the procedure summarized in the following paragraphs and the isolates exhibiting appreciable surfactant activity were selected and subjected to identification and further production.

2.3. Morphological, Physiological and Biochemical Characteristics of Marine Isolates. The strains isolated from marine sediments were identified by conventional biochemical tests in accordance with Bergey's Manual of Systematic Bacteriology [32].

2.4. DNA Extraction. Genomic DNA was isolated and purified by "Dneasy Tissue Kit” (Qiagen GmgH, Hilden, Germany) according to the manufacturer's directions. The quality of the extracted DNA was checked by agarose gel electrophoresis $2 \%(\mathrm{w} / \mathrm{v})$.

2.5. PCR Amplification: $16 S$ rRNA Gene Sequencing. To confirm the identities of the isolates, PCR amplification and sequencing of the $16 \mathrm{~S}$ rRNA gene were performed. The $16 \mathrm{~S}$ rRNA genes $(1,500 \mathrm{bp})$ were purified using the gel elution kit (Sigma-Aldrich, USA) as per the manufacturer's protocol using the bacterial universal primer set of 8F: $5^{\prime}$-AGAGTTTGATCCTGGCTCAG-3' and 1492R: $5^{\prime}$ GGCTACCTTGTTACGACTT- $3^{\prime}$ as described by Turner et al. [33]. Amplification was carried out with the eppendorf thermal cycler (Eppendorf North America Inc.) in a total volume of $25 \mu \mathrm{L}$ containing about $50 \mathrm{ng}$ of genomic DNA, $5 \mathrm{U}$ of Taq DNA polymerase, $20 \mathrm{pmol}$ of each primer, $200 \mu \mathrm{M}$ 


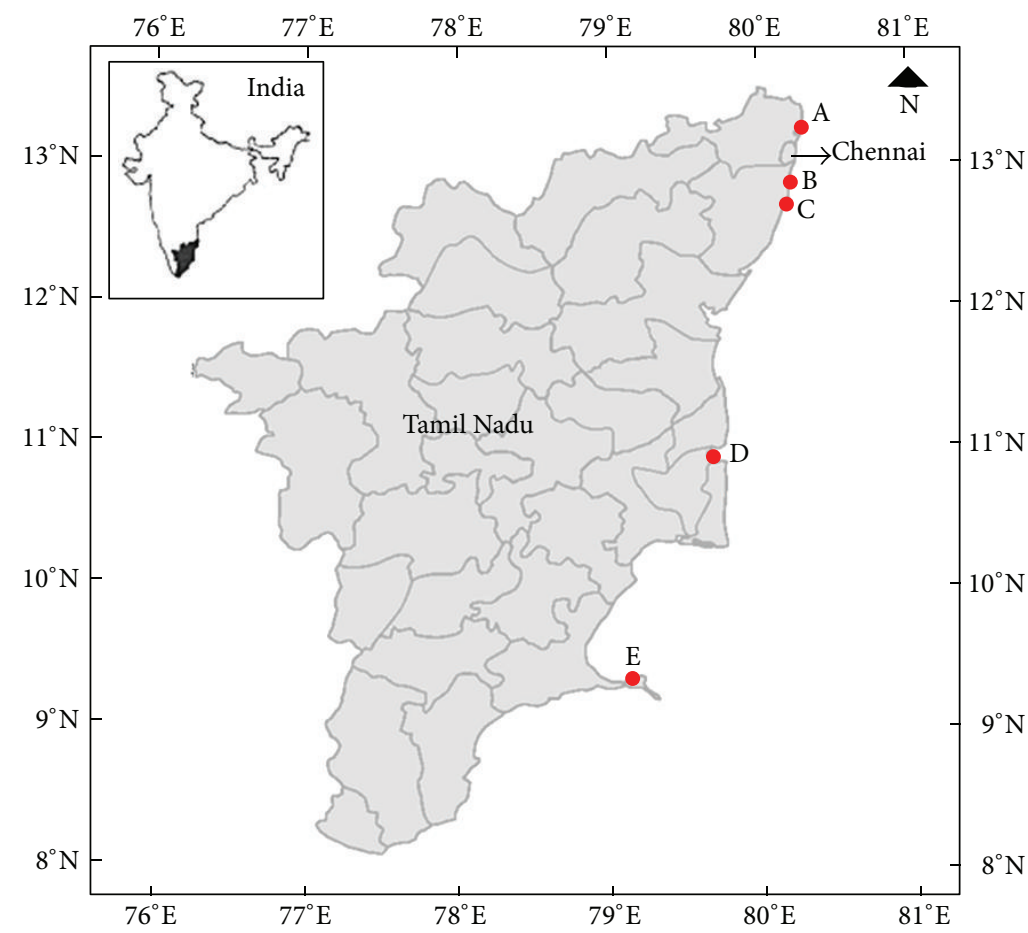

FIGURE 1: Location of the five sampling sites. Site coordinates limits (marine samples of water, sediments, mussels, shells, sea weeds, and sand): A is Ennore, Chennai, Tamilnadu; B is Mahabalipuram, Tamilnadu; C is Kalpakkam township, Tamilnadu; D is Cuddalore, Tamilnadu; E is Mandapam, Ramanathapuram, Tamilnadu.

dNTPs, and 1X Taq buffer with $1.5 \mathrm{mM} \mathrm{MgCl}_{2}$ according to the following program: $93^{\circ} \mathrm{C}$ for $2 \mathrm{~min}, 35$ cycles of $93^{\circ} \mathrm{C}$ for $1 \mathrm{~min}, 52^{\circ} \mathrm{C}$ for $2 \mathrm{~min}, 72^{\circ} \mathrm{C}$ for $2 \mathrm{~min}$, and final extension at $72^{\circ} \mathrm{C}$ for $5 \mathrm{~min}$. PCR products were analyzed by electrophoresis in $1 \%$ agarose.

2.6. Phylogenetic Analysis. For phylogenetic identification, the acquired sequences were used for a gene homology search with the $16 \mathrm{~S}$ rRNA gene sequences available in the public databases obtained from GenBank using the BLAST program (http://blast.ncbi.nlm.nih.gov/) [34] and ribosomal database project (http://rdp.cme.msu.edu/seqmatch/seqmatch_intro .jsp) [35]. Sequences retrieved from the GenBank database were aligned using the CLUSTAL omega [36], and tree was performed using three tree-making algorithms: neighbor-joining using Tamura-Nei distance parameters in the Geneious R6 program (available from http://www.geneious.com/).

2.7. Experimental Setup and Extraction of Surface Active Agents. All the selected isolates were cultured individually in $1000 \mathrm{~mL}$ Erlenmeyer flask containing $100 \mathrm{~mL}$ of Zobell marine broth and incubated at $37^{\circ} \mathrm{C}$ for $24-48$ hours under shaking condition. Followed by incubation, the cell-free supernatant was subjected to (equal amount of ice cold) ethanol precipitation according to Vater et al. [37]. The residual pellet was obtained upon centrifugation, dissolved in water, subjected to surface activity measurements, and designated as "microsurf".

\subsection{Surface Activity Measurements}

2.8.1. Drop Collapse Test. It is a rapid and crude method to assess the surfactant activity according to Jain et al. [38]. In brief, about $10 \mathrm{~mL}$ of cell free broth was added in the center of an oil drop ( $20 \mu \mathrm{L}$ of any oil) taken in a clean glass slide. The collapse of oil drop has been visualized and the less time taken indicates the higher activity of a surfactant. Activity of microbial surfactant was compared with water, synthetic (Tween 80 , SDS, CTAB) and commercially available biosurfactant (Surfactin).

2.8.2. Oil Displacement Method. This method is so sensitive and only a small amount of sample was required to measure the surfactant activity. About $10 \mathrm{~mL}$ of cell-free broth was placed in the center of oil $(50 \mu \mathrm{L}$ of any oil), which was formed on the surface of water in a large size petridish $(15 \mathrm{~cm}$ diameter). The size of the resultant oil-displaced circle area reflects the activity of a surfactant. The larger the size, the higher the activity of a surfactant [39]. A $50 \mu \mathrm{L}$ distilled water was used for negative control and $50 \mu \mathrm{L}$ of $0.1 \%$ Triton X 100 was used for positive control experiments.

2.8.3. Tensiometer Measurements. Surface tension of biosurfactant was measured by plate method using GBX-3S tensiometer (DM) at room temperature at different dilutions ranging from 1- to 10-fold [40]. A $10 \mathrm{~mL}$ of the cell free broth was taken in a clean glass beaker $(20 \mathrm{~mL})$ and was placed on tensiometer platform. A sterile plate was submerged into 
a solution and then slowly pulled through the liquid-air interface. Stabilization was allowed to occur until a standard deviation of 10 successive measurements was $<0.4 \mathrm{mN} / \mathrm{m}$. Each result was the average of 10 determinations after stabilization.

2.9. Assessment of Emulsifying Activity, Emulsification Index, and Stability of Emulsion of "Microsurf (1 to 5)." Followed by the measurement of biosurfactant activity, bioemulsification activity was determined using heptadecane (hydrocarbon) as substrate. In brief, we mixed $50 \mu \mathrm{L}$ of the sample (Microsurf (1 to 5)) with $1.0 \mathrm{~mL}$ of sodium acetate buffer ( $\mathrm{pH} 3.0$ ), then added $2 \mu \mathrm{L}$ of heptadecane and vortex. After 2-3 min, absorbance was measured at $540 \mathrm{~nm}$ using UV-visible spectrophotometer (Shimadzu, Japan). One unit of emulsifying activity was defined as the amount of biosurfactant that affected an emulsion with an absorbance at $540 \mathrm{~nm}$ of 1.0. To assess the emulsification index, $1.0 \mathrm{ml}$ of cell free broth was mixed with $1.0 \mathrm{ml}$ of various hydrocarbons (oils of sesame, peanut, sunflower, soybean, rice bran, and crude), benzene, toluene, and kerosene individually, vortex for $30 \mathrm{~min}$ and kept at room temperature. Emulsification index (E24) was calculated after 24 hours, by measuring the height of emulsion layer with respect to original volume.

For the assessment of stability of emulsion, emulsions obtained from above experiments were kept at room temperature for the period of 0-100 days. Visual observations were made for any phase separation such as, flocculation, creamy, and coalescence. Samples exhibiting nil phase separation were considered as stable emulsion.

2.10. Hemolytic Activity on Human Erythrocytes. To assess the hemolytic activity of "microsurf (1 to 5)" obtained from the above experiments, human RBC cells were used as substrates [41]. RBC suspension was incubated in the presence of isotonic solution of biosurfactants solution at room temperature for $10 \mathrm{~min}$ in the dark. The amount of hemoglobin released upon centrifugation $(3000 \times \mathrm{g})$ was measured at $540 \mathrm{~nm}$. RBC lysis with water was taken as $100 \%$, and sodium dodecyl sulfate (SDS) as reference compound.

2.11. Antimicrobial Activity. Antimicrobial activity of the "microsurf (1 to 5)" was made according to the CLSI [42] Standards for Antimicrobial Susceptibility Testing, using Gram positive and Gram negative species obtained from Microbial Type Culture Collection (MTCC), Chandigarh. In detail, Mueller-Hinton agar (MHA) was prepared from a commercially available dehydrated base according to the manufacturer's instructions. Followed by sterilization the media was poured in a glass petridishes. The agar medium was then allowed to cool to room temperature. For antimicrobial activity of "microsurf (1 to 5)," $50 \mu \mathrm{L}$ of (0.5 Mcfarland OD of MTCC strains) MTCC strains spread over the MHA plate and $0.5 \mathrm{~mm}$ well was made on the plate and different dilution of microsurf (1 to 5) was poured in the well and incubated at $37^{\circ} \mathrm{C}$.
2.12. Surfactant Gene (srf/sfp) Expression Analysis. Followed by identification and "microsurf" production, the gene of interest was designed from earlier reports [43] and studied according to the standard procedures. The primer pair srfA3/licA3F: CAAAAKCGCAKCATATGAG and srfA3/licA3R: AGCGGCAYATATTGATGCGGYTC was designed to amplify a 268 bp portion of the $s r f A 3$ or the homologous licA3 gene present in surfactin/lichenysinproducing strains of the $B$. subtilis/B. licheniformis. These primers were tested against five Bacillus strains. The srfA3/licA3 PCR reaction mix in a volume of $25 \mu \mathrm{L}$ reaction mixture consists of $2.5 \mathrm{U}$ of Taq DNA polymerase, $100 \mathrm{ng}$ of genomic DNA, 20 pmol of each primer, $200 \mu \mathrm{M}$ dNTPs, and $1 \mathrm{X}$ Taq buffer with $2 \mathrm{mM} \mathrm{MgCl}_{2}$. The thermal cycler was programmed for $2 \mathrm{~min}$ at $93^{\circ} \mathrm{C}$ for an initial denaturation cycle, 38 cycles of $35 \mathrm{~s}$ denaturation at $93^{\circ} \mathrm{C}, 35 \mathrm{~s}$ annealing at $48^{\circ} \mathrm{C}, 45 \mathrm{~s}$ extension at $72^{\circ} \mathrm{C}$, and followed by a $5 \mathrm{~min}$ final extension at $72^{\circ} \mathrm{C}$.

With reference to $s f p$ gene (the second gene essential to the production of surfactin) [44-46], PCR amplification was studied for all the five isolates with primer pairs specific to the $s f p$ gene. The $s f p 675 \mathrm{bp}$ fragment, corresponding to the B. subtilis sfp gene (GenBank accession number X63158) at positions 167-841, was amplified from the genomic DNA by PCR, using two oligonucleotide primers: $s f p$ F: $\left(5^{\prime}\right.$-ATGAAGATTTACGGAATTTA- $\left.3^{\prime}\right)$ and $s f p-\mathrm{R}:\left(5^{\prime}\right.$-TTATAAAAGCTCTTCGTACG-3'). Amplification was carried out with eppendorf thermal cycler (Eppendorf North America Inc.) in a total volume of $25 \mu \mathrm{L}$ containing about $200 \mu \mathrm{M}$ dNTPs, 1 X Taq buffer, 50 ng of genomic DNA, 20 pmol of each primer, and $3 \mathrm{U}$ Taq DNA polymerase. The thermal cycler was programmed for $1 \mathrm{~min}$ at $94^{\circ} \mathrm{C}$ for an initial denaturation cycle, 25 cycles of $1 \mathrm{~min}$ denaturation at $94^{\circ} \mathrm{C}, 30 \mathrm{~s}$ annealing at $46^{\circ} \mathrm{C}, 1 \mathrm{~min}$ extension at $72^{\circ} \mathrm{C}$, and followed by a $10 \mathrm{~min}$ final extension at $72^{\circ} \mathrm{C}$.

PCR products were analyzed by electrophoresis on $1 \%$ agarose. The expected DNA bands of $s r f / s f p$ 268/675 bp were excised from gel and purified using the gel elution kit (Sigma-Aldrich, USA) as per the manufacturer's protocol. The sequencing reactions were carried out for both the gene using a Big Dye Terminator Cycle Sequencing Kit (Applied Biosystems, Foster City, CA, USA). The sequences thus obtained were assembled and edited using Geneious R6.

2.13. DNA Sequence Accession Numbers. Accession numbers of sequences determined in this study were deposited in Genbank as isolate 1, HM145910, isolate 2, HM194725, isolate 3, HM222944, isolates 4 and 5, sequences submitted to NCBI.

\section{Results and Discussion}

3.1. The Marine Samples of Eastern Coastal Plain of Tamil $\mathrm{Nadu}$. The marine samples collected from eastern coastal plain of Tamil Nadu were subjected to the microbial profile with respect to biosurfactant production which implied that only $9.0 \%$ of the bacterial have population shown biosurfactant production. However, the remaining populations displayed secondary metabolites other than biosurfactants. It 

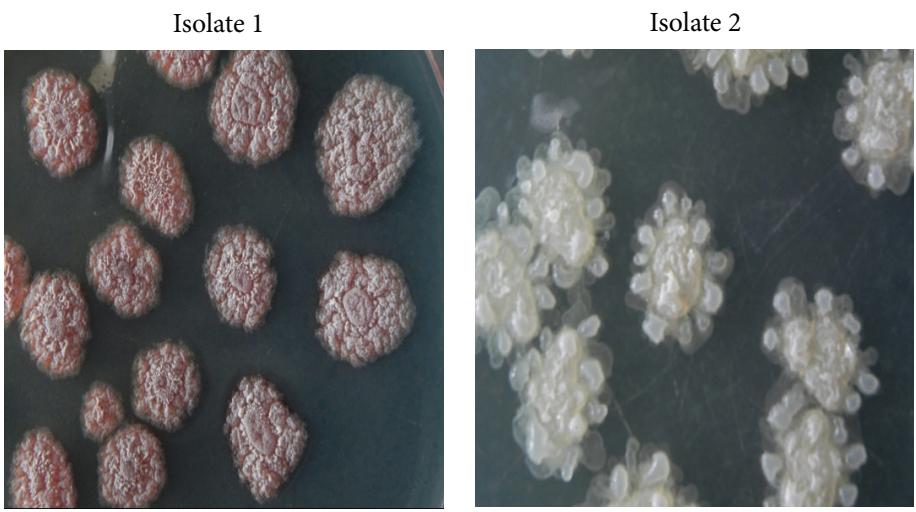

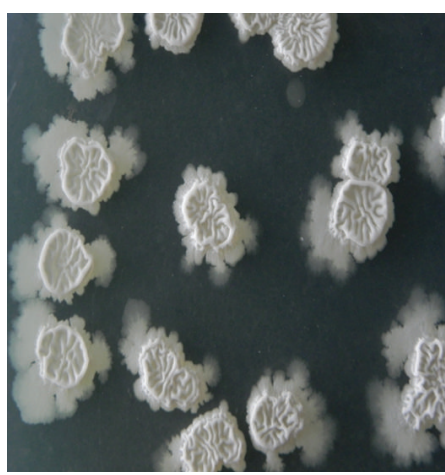

Isolate 3

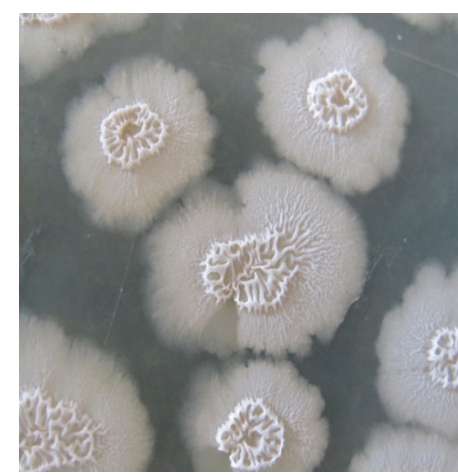

Isolate 4

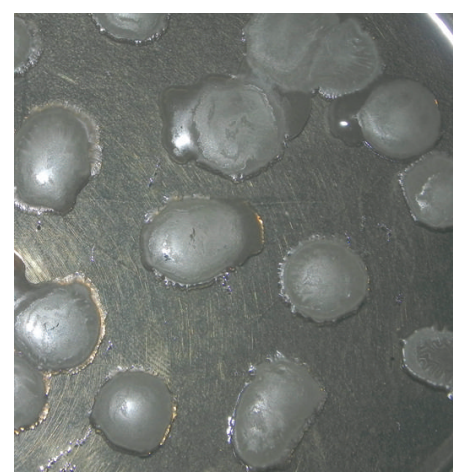

Isolate 5

FIgUre 2: Plate morphology of the five different marine isolates (isolate-1; isolate-2; isolate-3; isolate-4; isolate-5).

could be reasoned to the less oil pollution but with greater pharmaceutical waste contaminations. Even the samples of Ennore port and Tuticorin port also showed less biosurfactant producers. It can be argued that the sampling seasons may play the role in the specific microbial populations. However, to avoid this argument, sampling was done at three different seasons and in all the scheduled time periods, only less number of biosurfactant producers were encountered. But, still, the sampling studies need much more explorations.

\subsection{Phenotypic and Biochemical Characteristics. Screening} and identifications studies revealed that the selected isolates were confirmed as the members of the genus Bacillus phenotypically and genotypically. With respect to phenotypic characteristics, most of the colonies were smooth, white in colour, and having regular margin and some of the microbes have rough, dry, irregular margin; and some have slimy with smooth colonies and one isolate exhibited filamentous growth with pigment production on agar plate (Figure 2). Though most of the reports on Bacillus species infer nil pigmentation, however, the pigmented colonies of one of the isolates observed in the present study correlate well with the report of Palmisano et al. [47]. With reference to Gram staining, the isolates were Gram positive rod-shaped and dominated in the size range of $0.5-1.2 \mu \mathrm{m}$. All the isolates were motile and spore producers.

Biochemical analysis revealed that all five isolates were positive for catalase and one isolate showed positive for oxidase. All five isolates showed hydrolysis of casein, gelatin, starch, and lipid. Few isolates were not responsive to the IMViC test. Table 1 describes the results on the biochemical analysis of the biosurfactant producers.

3.3. Molecular Characterization. Results on phenotypic characteristics and 16S rRNA gene sequence homology suggested that all the five isolates have shown close relativeness to genus Bacillus (Table 2). Isolates 1 and 2 share an almost identical 16S rRNA gene sequence with the published species B. licheniformis ATCC 14580 and B. licheniformis DSM13 = ATCC 14580 (94\% and 99\% similarity), whereas isolates 3, 4 , and 5 share an almost identical $16 \mathrm{~S}$ rRNA gene sequence with the published species $B$. subtilis RO-NN-1 chromosome, Bacillus spp. JS chromosome, and B. subtilis BEST7613 DNA with sequence homology (100\% similarity). The phylogenetic framework was constructed based on the sequence analysis constructed by neighbor-joining method based on $16 \mathrm{~S}$ rRNA gene sequence (Figure 3). It has been understood that all five isolates are closely related to $B$. subtilis with meager variations. Results of Roberts et al. [26, 27], and Nakamura [28] also observed the similar relativeness in B. subtilis with other Bacillus spp.

With respect to biosurfactant activity of the isolates, the cell-free broth was subjected to drops collapse test, oil displacement test, and tensiometer measurements. The biosurfactant activity was compared with commercially available biosurfactant, synthetic surfactant, and water. All the isolates 
TABLE 1: Phenotypic and biochemical characteristic of marine isolates.

\begin{tabular}{|c|c|c|c|c|c|}
\hline Characteristics & Isolate 1 & Isolate 2 & Isolate 3 & Isolate 4 & Isolate 5 \\
\hline Morphology & $\begin{array}{l}\text { Pink, dry, and } \\
\text { filamentous }\end{array}$ & $\begin{array}{l}\text { White, smooth, and } \\
\text { irregular colonies }\end{array}$ & $\begin{array}{l}\text { White, smooth, } \\
\text { circular, and undulate } \\
\text { margin }\end{array}$ & $\begin{array}{l}\text { White, circular, and } \\
\text { smooth margin }\end{array}$ & $\begin{array}{l}\text { White, smooth, slimy, } \\
\text { and entire margin }\end{array}$ \\
\hline Gram stain & + & + & + & + & + \\
\hline Shape & Rod & Rod & Rod & Rod & Rod \\
\hline Motility & Motile & Motile & Motile & Motile & Motile \\
\hline Indole & - & - & - & - & - \\
\hline Methyl red & - & - & - & - & - \\
\hline Voges Proskauer & + & + & + & + & + \\
\hline Citrate & + & + & + & + & + \\
\hline Urease & - & - & - & - & + \\
\hline Nitrate & + & + & - & - & + \\
\hline Oxidase & + & - & - & - & - \\
\hline Catalase & + & + & + & + & + \\
\hline Starch hydrolysis & + & + & + & + & + \\
\hline Casein hydrolysis & + & + & + & + & + \\
\hline Lipid hydrolysis & + & + & + & + & + \\
\hline Gelatin hydrolysis & + & + & + & + & + \\
\hline Growth at $55^{\circ} \mathrm{C}$ & + & + & - & - & - \\
\hline \multicolumn{6}{|l|}{ Growth in $\mathrm{NaCl}$} \\
\hline $5 \%$ & + & + & + & + & + \\
\hline $7.5 \%$ & + & + & + & + & + \\
\hline
\end{tabular}

(+): positive; (-): negative.

TABLE 2: 16S rRNA sequence homology. Identification and comparison of the bacterial isolates from marine environment.

\begin{tabular}{|c|c|c|c|}
\hline \multirow{2}{*}{ Isolates } & \multicolumn{3}{|c|}{ The best GenBank match } \\
\hline & $\begin{array}{c}\text { Classification } \\
\text { (accession number) }\end{array}$ & $\begin{array}{c}\% \\
\text { homology }\end{array}$ & $\begin{array}{c}\% \\
\text { coverage }\end{array}$ \\
\hline Isolate 1 & $\begin{array}{c}\text { B. licheniformis ATCC } \\
14580(\text { NC006270.3) }\end{array}$ & $94 \%$ & $99 \%$ \\
\hline Isolate 2 & $\begin{array}{c}\text { B. licheniformis DSM13 = ATCC } \\
14580(\mathrm{NC} 006270.1)\end{array}$ & $99 \%$ & $100 \%$ \\
\hline Isolate 3 & $\begin{array}{c}\text { B. subtilis RO-NN-1 } \\
\text { chromosome (NC019948.1) }\end{array}$ & $100 \%$ & $100 \%$ \\
\hline Isolate 4 & $\begin{array}{c}\text { Bacillus spp. JS chromosome } \\
\text { (NC017743.1) }\end{array}$ & $100 \%$ & $100 \%$ \\
\hline Isolate 5 & $\begin{array}{c}\text { B. subtilis BEST7613 DNA } \\
(\mathrm{NC019948.1)}\end{array}$ & $100 \%$ & $99 \%$ \\
\hline
\end{tabular}

collapse the oil but differ at the time taken for collapsing the oil with respect to organism. Table 3 describes results on the drops collapse test and oil displacement test, and tensiometer measurements suggested that all the five marine isolates exhibit appreciable biosurfactants activity which was on par with synthetic surface active agents, and Table 4 illustrates the chemical composition of biosurfactant obtained from marine isolates. Followed by the production, recovery of biosurfactant by precipitation processes was carried out. Ethanol precipitated biosurfactant (designated as "microsurf
TABLE 3: Surfactant activity of the 5 marine isolates.

\begin{tabular}{lccc}
\hline Isolate & DCT & ODT & TM $(\mathrm{mN} / \mathrm{m})$ \\
\hline Isolate 1 & +++ & +++ & $28 \pm 3$ \\
Isolate 2 & +++ & +++ & $31 \pm 2$ \\
Isolate 3 & ++ & + & $29 \pm 4$ \\
Isolate 4 & +++ & +++ & $30 \pm 2$ \\
Isolate 5 & +++ & +++ & $26 \pm 4$ \\
\hline
\end{tabular}

$(+++)$ : excellent; $(++)$ : good; (+): average [DCT: drop collapse test; ODT: oil displacement test; TM: tensiometer measurement].

(1 to 5) respective to isolate 1 to isolate 5 ") was creamy white in colour and soluble in water and dimethyl sulfoxide.

Examination of emulsification activity, emulsification index and stability of emulsion reveal, emulsification index of $85-95 \%$ was observed with vegetable oils and crude oil and $<75 \%$ with kerosene. With regard to the stability of emulsions, stable emulsion was observed with vegetable oils (more than 90 days) more than emulsion formed with kerosene (only up to 30 days) and crude oil. Followed by the emulsion formation, we observed a complete transformation of emulsion to thread like structures in crude oil and reasons to less stability. With reference to hemolytic activity, no haemolysis was exhibited by the "microsurf (1 to 5)" even at high concentration. The nonhemolytic behaviour of "microsurf (1 to 5)" in comparison with standard surfactin observed in the present study may be due to the nonionic nature of the 
TABLE 4: Chemical composition of biosurfactants obtained from marine isolates.

\begin{tabular}{lcccccc}
\hline Marine isolates & $\begin{array}{c}\text { Lipid content } \\
(\mu \mathrm{g} / \mathrm{mL})\end{array}$ & $\begin{array}{c}\text { Protein content } \\
(\mu \mathrm{g} / \mathrm{mL})\end{array}$ & $\begin{array}{c}\text { Carbohydrate } \\
\text { content }(\mu \mathrm{g} / \mathrm{mL})\end{array}$ & Haemolytic activity & $\begin{array}{c}\text { Antimicrobial } \\
\text { activity }\end{array}$ & Ionic character \\
\hline Microsurf-1 & 17.5 & 103.3 & 8.61 & Nonhaemolytic & No activity & Nonionic \\
Microsurf-2 & 7.59 & 80.28 & 2.65 & Nonhaemolytic & No activity & Nonionic \\
Microsurf-3 & 69.1 & 16.73 & 0.72 & Nonhaemolytic & No activity & Nonionic \\
Microsurf-4 & 17.78 & 20.55 & 7.19 & Nonhaemolytic & No activity & Nonionic \\
Microsurf-5 & 9.7 & 5.39 & 0.235 & Nonhaemolytic & No activity & Nonionic \\
Standard & - & - & - & Haemolytic & Broad spectrum & Anionic \\
(surfactin) & & & & & &
\end{tabular}

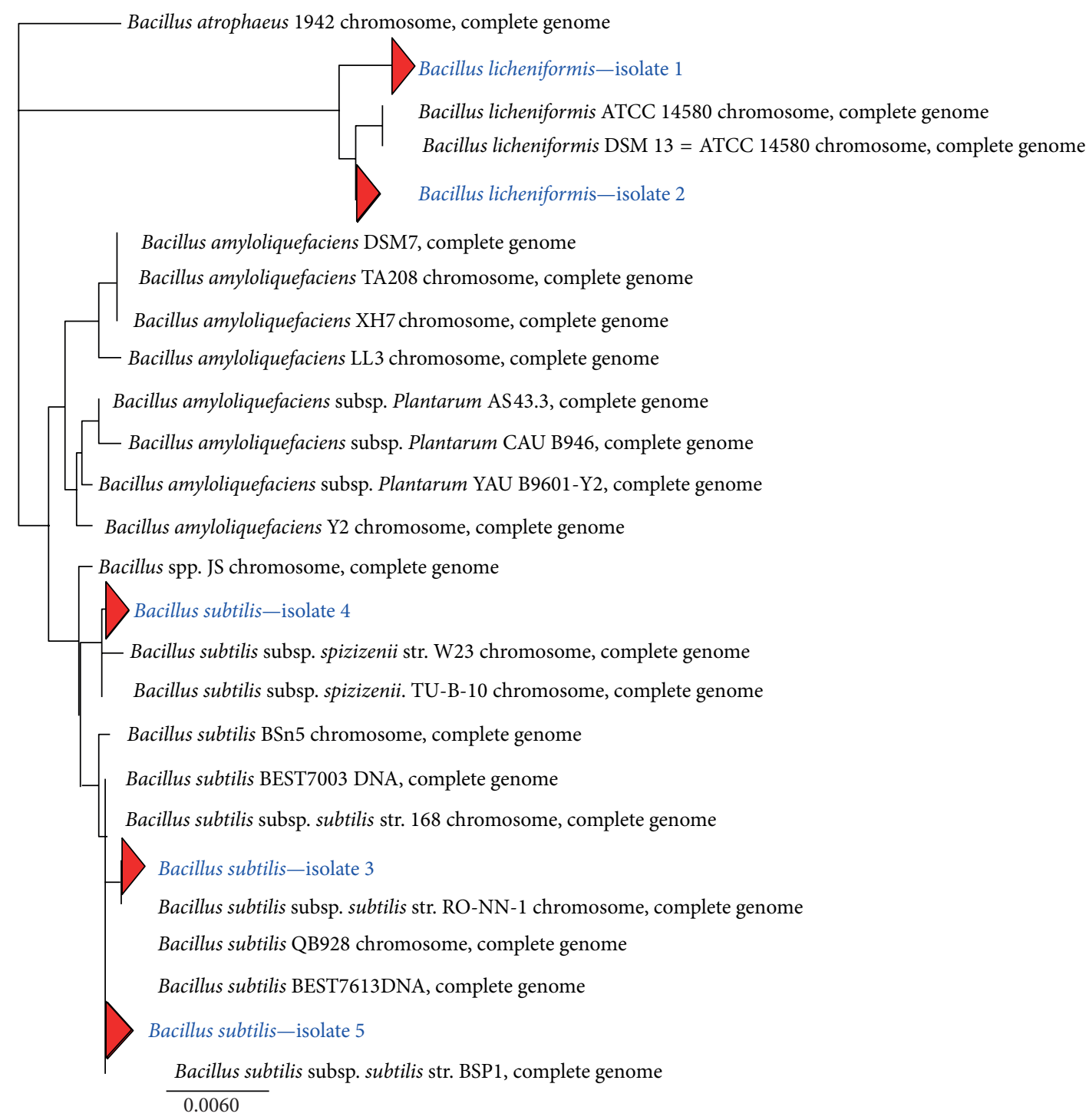

FIgURE 3: Phylogenetic tree of 16S rRNA gene sequences of the marine isolates. Bar, 0.006 substitutions per nucleotide position.

"microsurf." The reason for the nonionic nature has not been understood yet. However, according to the literatures, the presence of aminoacid determines the ionic characteristic of biosurfactant. And moreover, the presence of alanine may also contribute to the nonhemolytic behaviour [48]. Further, the nonantimicrobial activity of "microsurf" has also been reasoned to the nonionic nature.

3.4. Identification of Gene of Interest and Sequence Determination of PCR Amplified Product. Figure 4(a) illustrates 


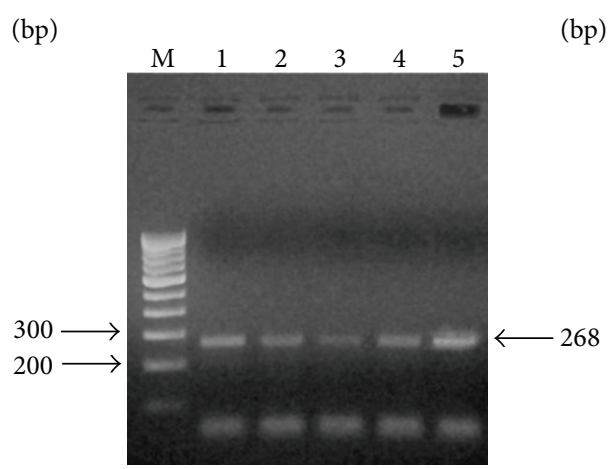

(a)

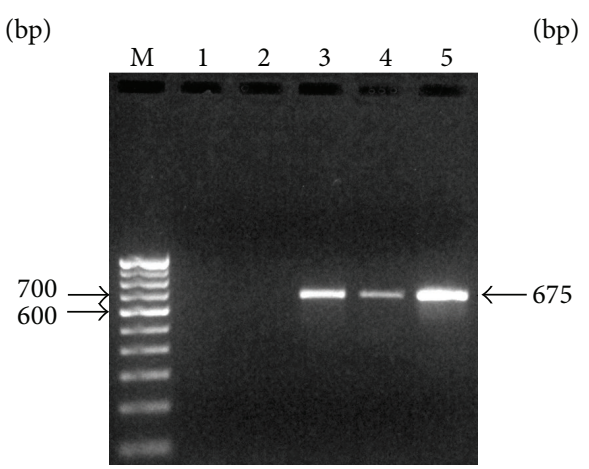

(b)

FIGURE 4: PCR amplification of $\operatorname{srf}$ (a) and $s f p$ (b) gene in the chosen marine isolates. [M-molecular size marker (100 bp ladder); Lane 1 is $B$. licheniformis (isolate 1); Lane 2 is B. licheniformis (isolate 2); Lane 3 is B. subtilis (isolate 3); Lane 4 is B. subtilis (isolate 4), and Lane 5 is B. subtilis (isolate 5)].

the PCR amplification of srf genes in all the five isolates. It has been observed that all of the five isolates express srf gene amplification at $268 \mathrm{bp}$. However, the expression of $s f p$ gene amplified at $675 \mathrm{bp}$ was realized only for three isolates (Figure $4(\mathrm{~b})$ ). The $s f p$ gene is an essential component of peptide synthesis systems and also plays a role in the regulation of surfactin biosynthesis gene expression [42]. The sequences $s r f / s f p$ thus obtained were verified in the NCBI databases for the gene/species confirmation, thus validating the presence of the genes in the selected strains of Bacillus.

According to the existing literatures, discrimination of Bacillus species was assessed based on the (i) morphology; (ii) biochemical; (iii) genes responsible for the particular metabolite production/or molecular profile; and finally (iv) the structural features of the metabolites/enzymes. Nevertheless, still, the variation at subspecies levels has been realized by a number of researchers. In the present study, discrimination in Bacillus species was made based on the biosurfactant production. Since there was no clear report on the actual steps involved in the synthesis of surface active agents by Bacillus species and numbers of hypotheses have been explored by the researchers. The entire said hypothesis as a whole suggested that biosurfactant produced has been categorized as surfactin, though there has been the difference in the structural features. The major difference was observed in lipid moiety and the peptide sequence. Furthermore, the researchers have also realized the difference in the ionic nature, hemolytic behavior, and antimicrobial properties, although, the organisms displayed the gene responsible for surfactin. It has been observed that surfactin of one Bacillus species is entirely different from the surfactin of other Bacillus species. But only few reports illustrate $>99 \%$ matching with the commercially available surfactin.

In the present study, though the surface active agent of $B$. licheniformis and $B$. subtilis showed similarity among them, the gene of expression clearly demonstrated the difference. srf expression was observed in both $B$. licheniformis and $B$. subtilis, whereas sfp expression was realized only with $B$. subtilis. It has been suggested that in B. licheniformis the integration between $s r f$ and $s f p$ genes may not occur, which limits the expression of $s f p$ gene, whereas the integration between said genes in $B$. subtilis expresses the $s f p$ gene. It may also be argued that the selection of primers could be one of the reasons or the directed de nova synthesis may hinder the expression of $s f p$.

\section{Conclusion}

The present study deals with the discrimination in surfactinlike biosurfactant extracted from marine Bacillus species of Tamil coastal plain that was studied in detail and the expression of genes responsible for surface active agent demonstrated wide variations, which added an additional information for the Gram positive bacterial species of marine origin.

On comparing these observations with the reported literatures it has been concluded that Bacillus spp. of Tamil Nadu coastal plains have the capacity to produce biosurfactant, having similar or more or less equal surfactant activity compared to other Bacillus spp. but displayed nonionic and nonhemolytic behaviour. This property of the biosurfactant is interesting and needs explorations. Among the B. licheniformis and B. subtilis species, the gene specific to biosurfactant production ( $s f p$ ) has been expressed in $B$. subtilis and not in B. licheniformis.

\section{Conflict of Interests}

The authors declare that there is no conflict of interests regarding the publication of this paper.

\section{Acknowledgment}

The authors greatly acknowledge DBT, New Delhi, CSIR Network Project (CSC0127), for financial assistance in the form of projects. 


\section{References}

[1] E. Bååth, M. Díaz-Raviña, Å. Frostegård, and C. D. Campbell, "Effect of metal-rich sludge amendments on the soil microbial community," Applied and Environmental Microbiology, vol. 64, no. 1, pp. 238-245, 1998.

[2] G. M. König, S. Kehraus, S. F. Seibert, A. Abdel-Lateff, and D. Müller, "Natural products from marine organisms and their associated microbes," ChemBioChem, vol. 7, no. 2, pp. 229-238, 2006.

[3] G. Georgiou, S.-C. Lin, and M. M. Sharma, "Surface-active compounds from microorganisms," Nature Biotechnology, vol. 10, no. 1, pp. 60-65, 1992.

[4] S. H. Kim, E. J. Lim, S. O. Lee, J. D. Lee, and T. H. Lee, "Purification and characterization of biosurfactants from Nocardia sp. L-417," Biotechnology and Applied Biochemistry, vol. 31, no. 3, pp. 249-253, 2000.

[5] N. Youssef, M. S. Elshahed, and M. J. McInerney, "Chapter 6 microbial processes in oil fields: culprits, problems, and opportunities," Advances in Applied Microbiology, vol. 66, pp. 141-251, 2009.

[6] W.-Q. Zhuang, J.-H. Tay, A. M. Maszenan, and S. T. L. Tay, "Bacillus naphthovorans sp. nov. from oil-contaminated tropical marine sediments and its role in naphthalene biodegradation," Applied Microbiology and Biotechnology, vol. 58, no. 4, pp. 547553, 2002.

[7] G. J. Dick, Y. E. Lee, and B. M. Tebo, "Manganese(II)-oxidizing Bacillus spores in Guaymas basin hydrothermal sediments and plumes," Applied and Environmental Microbiology, vol. 72, no. 5, pp. 3184-3190, 2006.

[8] N. Fusetani, D. Ejima, S. Matsunaga et al., "3-Amino-3-deoxyD-glucose: an antibiotic produced by a deep-sea bacterium," Experientia, vol. 43, no. 4, pp. 464-465, 1987.

[9] Y. Ohta, Y. Nogi, M. Miyazaki et al., "Enzymatic properties and nucleotide and amino acid sequences of a thermostable $\beta$ agarase from the novel marine isolate, JAMB-A94," Bioscience, Biotechnology and Biochemistry, vol. 68, no. 5, pp. 1073-1081, 2004.

[10] C. R. Harwood, "Bacillus," in Biotechnology Handbooks, T. Atkinson and R. F. Sherwood, Eds., Plenum, New York, NY, USA, 1989.

[11] S. Lang and D. Wullbrandt, "Rhamnose lipids-biosynthesis, microbial production and application potential," Applied Microbiology and Biotechnology, vol. 51, no. 1, pp. 22-32, 1999.

[12] I. M. Banat, R. S. Makkar, and S. S. Cameotra, "Potential commercial applications of microbial surfactants," Applied Microbiology and Biotechnology, vol. 53, no. 5, pp. 495-508, 2000.

[13] T. T. Nguyen, N. H. Youssef, M. J. McInerney, and D. A. Sabatini, "Rhamnolipid biosurfactant mixtures for environmental remediation," Water Research, vol. 42, no. 6-7, pp. 1735-1743, 2008.

[14] A. S. Nerurkar, "Structural and molecular characteristics of lichenysin and its relationship with surface activity," in Biosurfactants, vol. 672 of Advances in Experimental Medicine and Biology, pp. 304-315, Springer, New York, NY, USA, 2010.

[15] E. P. Ivanova, M. V. Vysotskii, V. I. Svetashev et al., "Characterization of Bacillus strains of marine origin," International Microbiology, vol. 2, no. 4, pp. 267-271, 1999.

[16] J. L. Siefert, M. Larios-Sanz, L. K. Nakamura et al., "Phylogeny of marine Bacillus isolates from the Gulf of Mexico," Current Microbiology, vol. 41, no. 2, pp. 84-88, 2000.
[17] C. A. C. Miranda, O. B. Martins, and M. M. Clementino, "Species-level identification of Bacillus strains isolates from marine sediments by conventional biochemical, 16S rRNA gene sequencing and inter-tRNA gene sequence lengths analysis," Antonie van Leeuwenhoek, vol. 93, no. 3, pp. 297-304, 2008.

[18] F. G. Priest, "Systematics and ecology of Bacillus," in Bacillus Subtilis and Other Gram-Positive Bacteria: Biochemistry, Physiology, and Molecular Genetics, A. L. Sonenshein, J. A. Hoch, and R. Losick, Eds., pp. 3-16, American Society for Microbiology, Washington, DC, USA, 1993.

[19] E. A. Gontang, W. Fenical, and P. R. Jensen, "Phylogenetic diversity of gram-positive bacteria cultured from marine sediments," Applied and Environmental Microbiology, vol. 73, no. 10, pp. 3272-3282, 2007.

[20] P. Cosmina, F. Rodriguez, F. de Ferra et al., "Sequence and analysis of the genetic locus responsible for surfactin synthesis in Bacillus subtilis," Molecular Microbiology, vol. 8, no. 5, pp. 821831, 1993.

[21] D. Konz, S. Doekel, and M. A. Marahiel, "Molecular and biochemical characterization of the protein template controlling biosynthesis of the lipopeptide lichenysin," Journal of Bacteriology, vol. 181, no. 1, pp. 133-140, 1999.

[22] N. H. Youssef, K. E. Duncan, and M. J. McInerney, "Importance of 3-hydroxy fatty acid composition of lipopeptides for biosurfactant activity," Applied and Environmental Microbiology, vol. 71, no. 12, pp. 7690-7695, 2005.

[23] R. Sen, "Surfactin: biosynthesis, genetics and potential applications," in Biosurfactants, vol. 672 of Advances in Experimental Medicine and Biology, pp. 316-323, Springer, New York, NY, USA, 2010

[24] F. Peypoux, J. M. Bonmatin, and J. Wallach, "Recent trends in the biochemistry of surfactin," Applied Microbiology and Biotechnology, vol. 51, no. 5, pp. 553-563, 1999.

[25] T. Nishikiori, H. Naganawa, Y. Muraoka, T. Aoyagi, and H. Umezawa, "Plipastatins: new inhibitors of phospholipase A2, produced by Bacillus cereus BMG302-fF67 II. Structure of fatty acid residue and amino acid sequence," Journal of Antibiotics, vol. 39, no. 6, pp. 745-745, 1986.

[26] M. S. Roberts, L. K. Nakamura, and F. M. Cohan, "Bacillus mojavensis sp. nov., distinguishable from Bacillus subtilis by sexual isolation, divergence in DNA sequence, and differences in fatty acid composition," International Journal of Systematic Bacteriology, vol. 44, no. 2, pp. 256-264, 1994.

[27] M. S. Roberts, L. K. Nakamura, and F. M. Cohan, "Bacillus vallismortis sp. nov., a close relative of Bacillus subtilis, isolated from soil in Death Valley, California," International Journal of Systematic Bacteriology, vol. 46, no. 2, pp. 470-475, 1996.

[28] L. K. Nakamura, "Taxonomic relationship of black-pigmented Bacillus subtilis strains and a proposal for Bacillus atrophaeus sp. nov," International Journal of Systematic Bacteriology, vol. 39, no. 3, pp. 295-300, 1989.

[29] A. Ventosa, M. T. Garcia, M. Kamekura, H. Onishi, and F. Ruiz-Berraquero, "Bacillus halophilus sp. nov., a moderately halophilic Bacillus species," Systematic and Applied Microbiology, vol. 12, no. 2, pp. 162-166, 1989.

[30] S. Spring, W. Ludwig, M. C. Marquez, A. Ventosa, and K.H. Schleifer, "Halobacillus gen. nov., with descriptions of Halobacillus litoralis sp. nov. and Halobacillus trueperi sp. nov., and transfer of Sporosarcina halophila to Halobacillus halophilus comb. nov," International Journal of Systematic Bacteriology, vol. 46, no. 2, pp. 492-496, 1996. 
[31] M. J. Garabito, D. R. Arahal, E. Mellado, M. C. Márquez, and A. Ventosa, "Bacillus salexigens sp. nov., a new moderately halophilic Bacillus species," International Journal of Systematic Bacteriology, vol. 47, no. 3, pp. 735-741, 1997.

[32] P. H. A. Sneath, "Endospore-forming gram-positive rods and cocci," in Bergey's Manual of Systematic Bacteriology, R. G. E. Murray, D. J. Brenner, and M. P. Bryant, Eds., pp. 1104-1207, The Williams \& Wilkins, Baltimore, Md, USA, 1986.

[33] S. Turner, K. M. Pryer, V. P. W. Miao, and J. D. Palmer, "Investigating deep phylogenetic relationships among cyanobacteria and plastids by small subunit rRNA sequence analysis," The Journal of Eukaryotic Microbiology, vol. 46, no. 4, pp. 327-338, 1999.

[34] S. F. Altschul, T. L. Madden, A. A. Schäffer et al., "Gapped BLAST and PSI-BLAST: a new generation of protein database search programs," Nucleic Acids Research, vol. 25, no. 17, pp. 3389-3402, 1997.

[35] J. R. Cole, Q. Wang, E. Cardenas et al., "The ribosomal database project: improved alignments and new tools for rRNA analysis," Nucleic Acids Research, vol. 37, supplement 1, pp. D141-D145, 2009.

[36] F. Sievers, A. Wilm, D. Dineen et al., "Fast, scalable generation of high-quality protein multiple sequence alignments using Clustal Omega," Molecular Systems Biology, vol. 7, p. 539, 2011.

[37] J. Vater, B. Kablitz, C. Wilde, P. Franke, N. Mehta, and S. S. Cameotra, "Matrix-assisted laser desorption ionization-time of flight mass spectrometry of lipopeptide biosurfactants in whole cells and culture filtrates of Bacillus subtilis C-1 isolated from petroleum sludge," Applied and Environmental Microbiology, vol. 68 , no. 12, pp. 6210-6219, 2002.

[38] D. K. Jain, D. L. C. Thompson, H. Lee, and J. T. Trevors, “A dropcollapsing test for screening surfactant-producing microorganisms," Journal of Microbiological Methods, vol. 13, no. 4, pp. 271279, 1991.

[39] M. Morikawa, H. Daido, T. Takao, S. Murata, Y. Shimonishi, and T. Imanaka, "A new lipopeptide biosurfactant produced by Arthrobacter sp. strain MIS38," Journal of Bacteriology, vol. 175, no. 20, pp. 6459-6466, 1993.

[40] A. A. Bodour and R. M. Miller-Maier, "Application of a modified drop-collapse technique for surfactant quantitation and screening of biosurfactant-producing microorganisms," Journal of Microbiological Methods, vol. 32, no. 3, pp. 273-280, 1998.

[41] M. Rosenberg, E. A. Bayer, J. Delarea, and E. Rosenberg, "Role of thin fimbriae in adherence and growth of Acinetobacter calcoaceticus RAG-1 on hexadecane," Applied and Environmental Microbiology, vol. 44, no. 4, pp. 929-937, 1982.

[42] CLSI, Performance Standards for Antimicrobial Susceptibility Testing, Seventeenth Informational Supplement, Wayne, Pa, USA, 2007.

[43] D. R. Simpson, N. R. Natraj, M. J. McInerney, and K. E. Duncan, "Biosurfactant-producing Bacillus are present in produced brines from Oklahoma oil reservoirs with a wide range of salinities," Applied Microbiology and Biotechnology, vol. 91, no. 4, pp. 1083-1093, 2011.

[44] M. M. Nakano, N. Corbell, J. Besson, and P. Zuber, "Isolation and characterization of $s f p$ : a gene that functions in the production of the lipopeptide biosurfactant, surfactin, in Bacillus subtilis," Molecular and General Genetics, vol. 232, no. 2, pp. 313321, 1992.

[45] F.-C. Hsieh, M.-C. Li, T.-C. Lin, and S.-S. Kao, "Rapid detection and characterization of surfactin-producing Bacillus subtilis and closely related species based on PCR," Current Microbiology, vol. 49, no. 3, pp. 186-191, 2004.

[46] G. Seydlová and J. Svobodová, "Review of surfactin chemical properties and the potential biomedical applications," Central European Journal of Medicine, vol. 3, no. 2, pp. 123-133, 2008.

[47] M. M. Palmisano, L. K. Nakamura, K. E. Duncan, C. A. Istock, and F. M. Cohan, "Bacillus sonorensis sp. nov., a close relative of Bacillus licheniformis, isolated from soil in the Sonoran Desert Arizona," International Journal of Systematic and Evolutionary Microbiology, vol. 51, no. 5, pp. 1671-1679, 2001.

[48] M. R. Infante, L. Perez, A. Pinazo, P. Clapes, and M. C. Moran, "Amino acid-based surfactants", in Novel Surfactants: Preparation, Application and Biodegradability, K. Holmberg, Ed., Surfactant Science Series, pp. 193-216, Marcel Dekker, New York, NY, USA, 114th edition, 2003. 

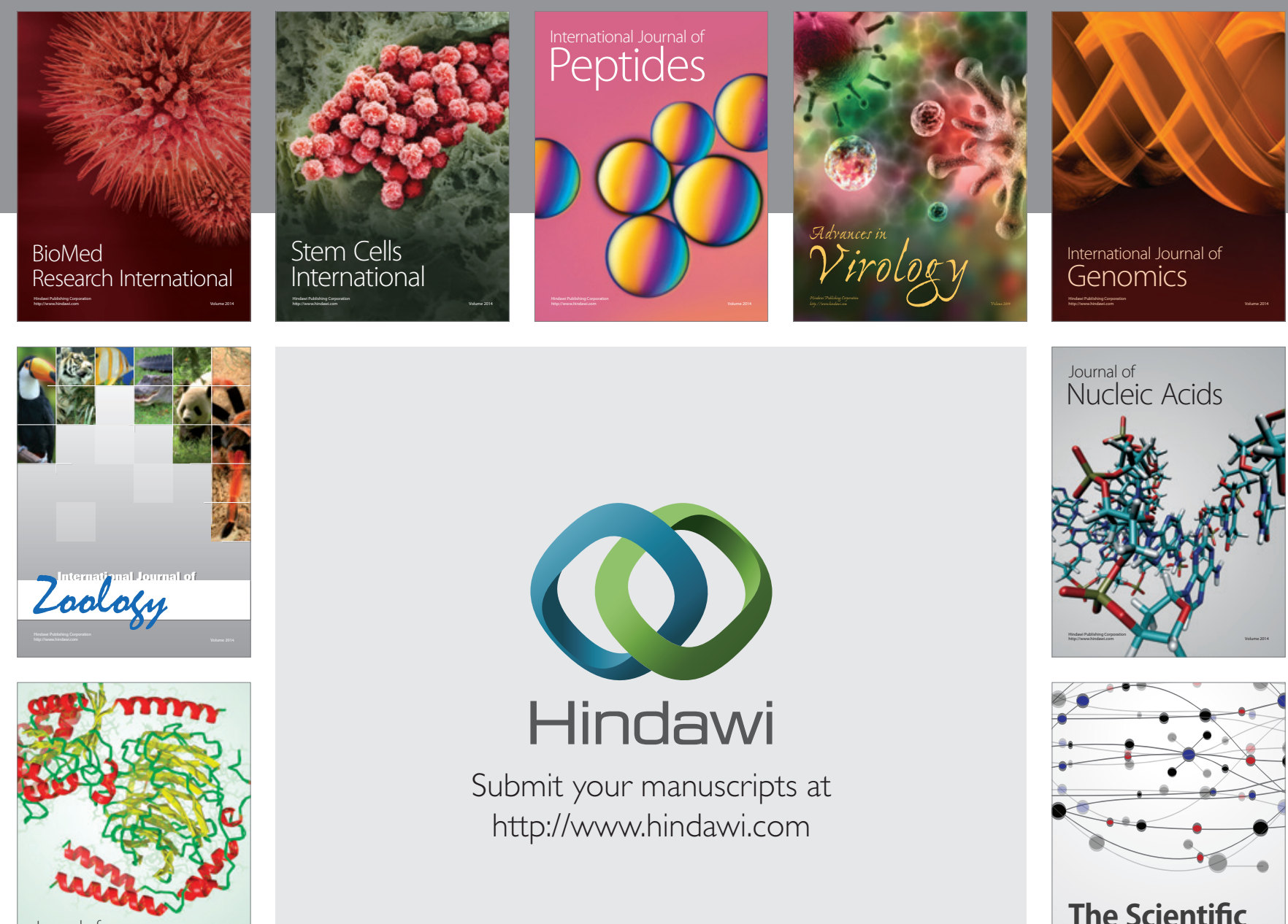

Submit your manuscripts at

http://www.hindawi.com

Journal of
Signal Transduction
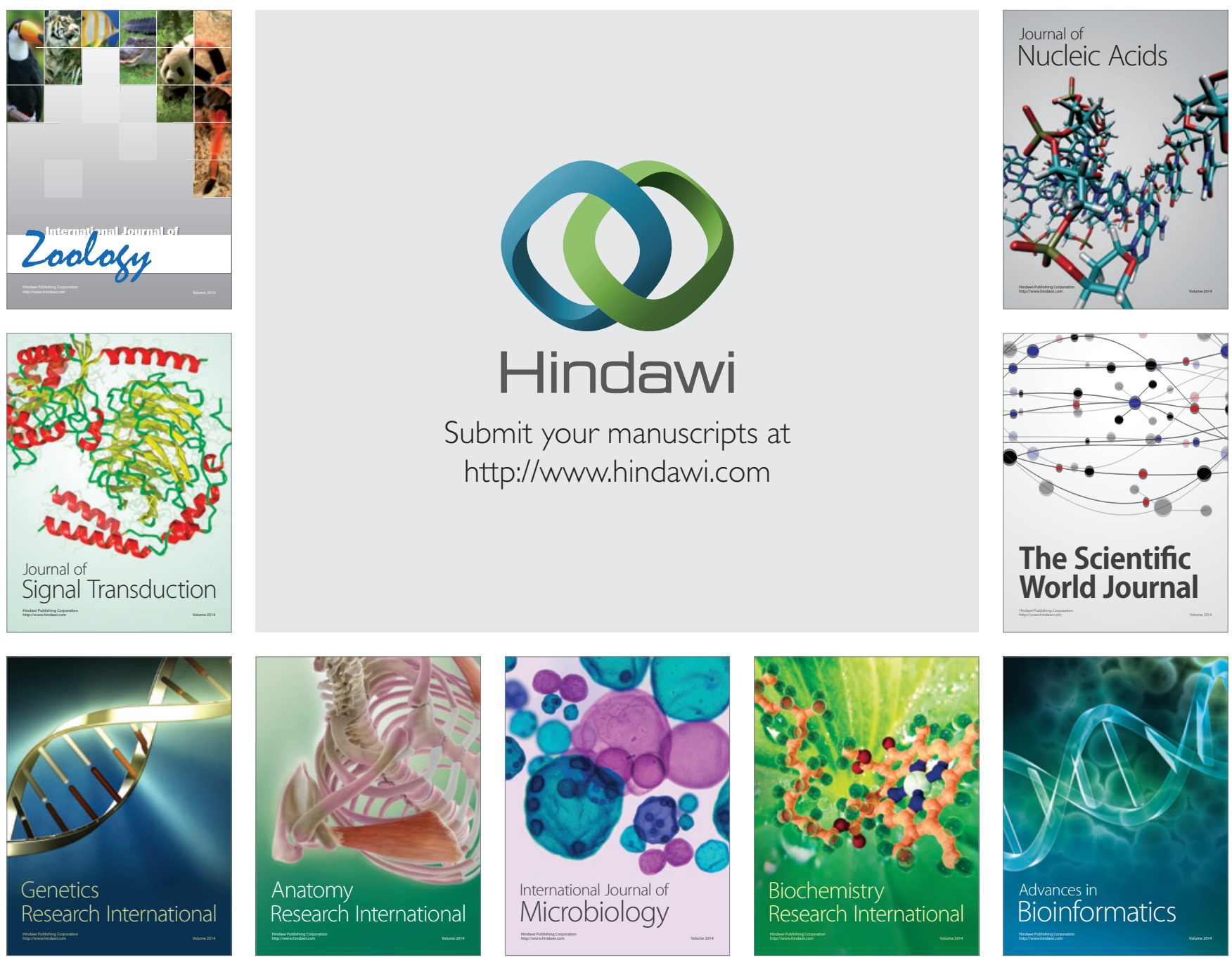

The Scientific World Journal
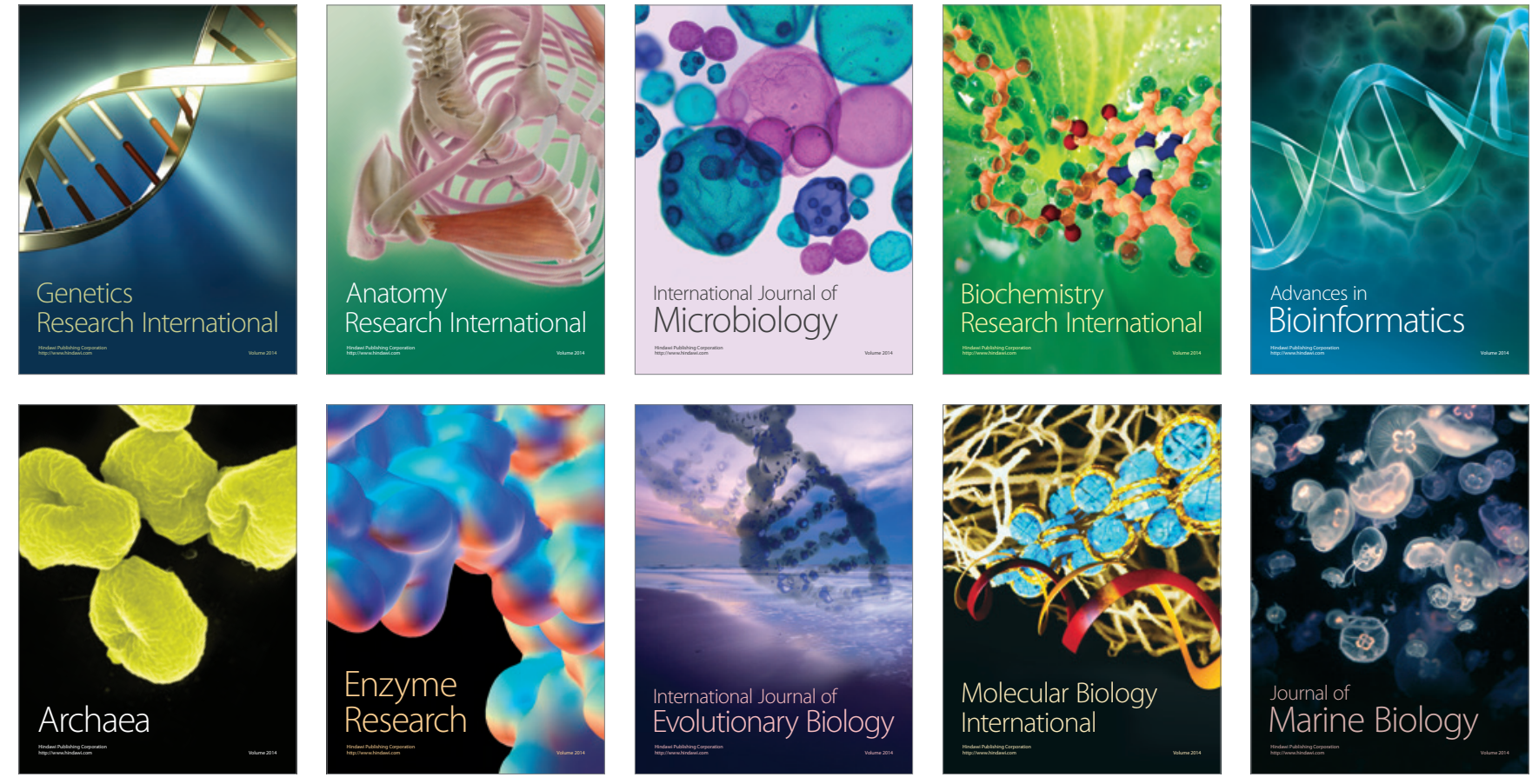